\title{
Coherence and Musical Meaning in Jazz Improvisation
}

\section{Coerência e Significado Musical na Improvisação do Jazz}

DOI: $10.46814 /$ lajdv3n4-002

Recebimento dos originais: 01/05/2021

Aceitação para publicação: 31/06/2021

\section{Dr. Julio Merlino}

Ph.D. in Music (UFRJ - 2019)

Adjunct Professor at the Woodwind and Percussion Department of the Music School

Federal University of Rio de Janeiro (UFRJ)

\begin{abstract}
In the context of improvised music, and more specifically in jazz-a situation in which at least part of the musical "work" is created at the moment it is perceived - the performers find themselves in an ambivalent condition: like their listeners at the same time they perform the music they experience it for the first time. Improvisers experience the musical content they produce in the act of improvisation as an improvised part of a "work" - an update of it. The "work", in this case, reveals itself at the moment of performance. In this work I discuss the understanding of musical coherence in order to support the investigation of cognitive processes involved in the act of jazz improvisation.
\end{abstract}

Keywords: Music cognition, musical coherence, musical meaning, musical improvisation.

\section{RESUMO}

No contexto da música improvisada, e mais especificamente no jazz - uma situação em que pelo menos parte da "obra" musical é criada no momento em que é percebida - os intérpretes encontram-se numa condição ambivalente: como os seus ouvintes, ao mesmo tempo executam a música que a experimentam pela primeira vez. Os improvisadores experimentam o conteúdo musical que produzem no acto de improvisação como uma parte improvisada de uma "obra" - uma actualização da mesma. A "obra", neste caso, revela-se no momento da execução. Neste trabalho discuto a compreensão da coerência musical, a fim de apoiar a investigação dos processos cognitivos envolvidos no acto de improvisação do jazz.

Palavras-chave: Cognição musical, coerência musical, significado musical, improvisação musical.

\section{INTRODUCTION}

${ }^{1}$ Linguistic metaphors are very often used to refer to music. We talk about phrases, themes, rhetoric, and most of all we speak of coherence and musical meaning. It is not difficult to understand

\footnotetext{
${ }^{1}$ This is a free translation made by the author himself form the original text in Brazilian Portuguese in June, 2021
} 
how a verbal text can be coherent and make sense, but how could we apply these same concepts to music? That seems to be at the core of many researches in the field of music cognition, although always mainly focused on inquiries about the meaning formation processes of a musical work composed beforehand its performance and identifiable as a particular item of a repertoire, in the fashion of the European written music tradition. The very notion of musical work has itself being debated many times from several different points of view. Among them, we can highlight those that differentiate musical work from musical object (Butterfield, 2002), others that advocate for a more ethereal vision, placing the musical piece somewhere between the musical sheet and its various performances (Rosenwald, 1993). Also, there are those who consider the musical work and its performances as parts of an inseparable procedural whole (Cook, 2001). This last argument being yet challenged by the defenders of the "objectification" of the musical work apart from the procedural aspects of the event-performance (Ingarden, 1986).

Here, we are faced with a different situation than that proposed by the listener-musical work paradigm. I am not proposing a new understanding of the musical meaning processes on behalf of the listener of an already established musical work, but the investigation of the very same processes from the performer him(her)self, who experiences the music for the first time while actually improvising. How does the processes of musical meaning formation takes place in improvised solos? Is there even the intent of accomplish that at all? There are those who say that this is exactly the case, that there are "crucial musical resource from which musicians build convincing solos and thematic continuity" (Monson, 2008, p. 123).

First, it is necessary to clarify which sort of improvisation I am referring to here and what do I mean by the word jazz (that here in most cases has nothing to do with the musical genre). Secondly, I discuss concepts of textual coherence and its applicability to music in order to better understand and illustrate these same topics for using them on a broader research work — of which this paper is a portion of an initial step — on the cognitive processes implicated in the musical meaning in jazz improvisation.

\section{IMPROVISATION AND JAZZ}

Despite its very broad meaning reaching out to various practices outside of the musical realms such as theater (Gesell, 2006, p. 15) or anthropology (Sawyer, 1999, p. 1), the word improvisation, when applied to musical practices, seems to be always associated with the homonymous musical genre (Beckstead, 2013, p. 69-71). To some authors improvisation and jazz are practically synonyms: "The term 'jazz' can refer to a wide range of improvisational behaviors and can be appropriated in many different ways, depending on the genre being referred to" (Zack, 2000, p. 228). This association is probably an inevitable consequence of the structural role improvisation played for the "jazz" genre 
since its origins in the beginning of the $20^{\text {th }}$ century in the USA, causing "jazz" to be confused with improvisation itself.

Even in the scope of "jazz" as a musical genre improvisation practices goes way beyond soloing. Think in improvisation in terms of "the creation of a musical work" or "the final form of a musical work, while it is being executed" (Nettl et al., 2017), already encompasses improvisational practices broader than the creations of melodic solo parts. In Nettl's mention of a "final form of a musical work" we can include not only the solo parts, but all the accompanying ones too executed by the rhythm section. Starting with the grooves played by the drummer to the bass lines and the guitar and the piano compings, to any other harmonic instrument, everything is improvised to a certain degree. Except for the drummer parts, all the others are usually written with chord symbols representing the harmonic progressions (or chord changes). The mere use of chord symbols already involves improvisation practices.

We can thus verify that improvisation is intrinsically linked to the practice of chord symbols writing. This form of writing emerged within a musical context where improvisation already existed.

\footnotetext{
Probably for this reason the chord symbols not only allows but also demanded this practice from musicians. (...) The use of chord symbols made improvisation necessary and also provided an excellent guide for it. With the chord symbols the improviser has all the written harmonic progression so that he can create all his improvisation over it. (...) improvisation is not only present but also gained even more strength with the use of this type of writing that directly involves it $^{2}$. (Merlino, 2008, p. 36-37).
}

In the context of the jazz genre, most of the time the rhythm section parts contain no instructions on what to play as an accompaniment, only the harmonic progressions represented in chord symbols and some rhythm cues (or obbligato parts), as exemplified in Figure 1:

Figure 1 Example of a written comping part.

Medium Swing Tempo $d=\mathbf{7 4}$

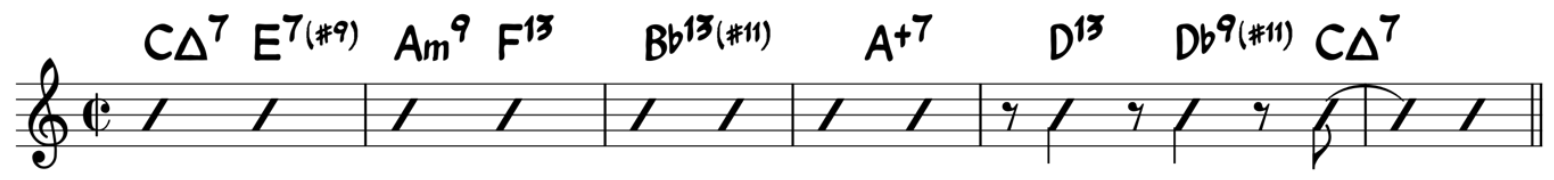

\footnotetext{
${ }^{2}$ Podemos verificar assim, que a improvisação está intrinsecamente ligada à prática da cifragem. Essa forma de escrita surgiu dentro de um contexto musical onde já existia a improvisação. Provavelmente por este motivo a cifragem não só permita, mas também demandava, dos músicos esta prática. (...) O emprego das cifras tornou essa improvisação necessária e também configurou um excelente guia para tal. O improvisador tem com a cifragem alfanumérica toda a progressão harmônica escrita, para que possa, sobre esta, criar toda a sua improvisação. (...) a improvisação não só está presente como também ganhou mais força ainda com a utilização deste tipo de escrita que a envolve diretamente.
} 
With chord symbols even if the musician is not a soloist improvising, for whom the part would function as a guide for the improvisation, many performing factors take place in an improvised manner, for the chord symbols specify the kind of chord should be played, but says nothing about both the spacial or temporal dispositions of the notes within it (the grooves, the assembling of the chords, all of this is improvised). Although these comping parts being of paramount importance for the music to actually happen, this is not the main interest of this paper. My main objective here is to investigate the coherence and musical meaning of the soloist melodic improvised parts.

As to the term "jazz", originally attached to musical genre, because of its globalization and subsequent absorption by many other cultural manifestations around the globe, came to be a way of categorizing an approach of musical performance: "jazz in 1980s and 1990s could no longer be restrictively described as 'African American', or even 'America's Classical Music': it was now an inextricable part of the world's musical culture" (Gioia, 1997, p. 376).

According to the chief sponsor of the Resolution no 57 of the US Congress from 1987-John Conyers - that declared jazz music as a north american national treasure, jazz was already present in many other countries in which the people thought of the jazz music they were playing was their own music (Walser, 2008, p. 301), probably resulting in all sorts of jazz fusions with many other musical genres. These hybrids were possibly the byproduct of mixing up other musical genres, preserving some of its core characteristics and implementing the one thing that is so owned by jazz music that is even confused with the music itself-improvisation. "There is no doubt that the single most important contribution to the revitalization of improvisation in Western music in the $20^{\text {th }}$ century is jazz" (Bailey, 1993, p. 48). In this way, what used to represent a musical genre characteristic of the USA, came to designate a way of playing whatever the genre. Therefore "the most fruitful understanding might result from shifting the emphasis from static characteristics to focus on the process involved in jazz performance" (Jackson, 2008, p. 90). "Jazz" it becomes any musical practice in which improvisation configures a structural element, which may be inserted in the context of bossa nova, frevo, salsa, rock, reggae, or any other musical genre.

For the terminological purposes of this study, it is understood that jazz improvisation is all that in which melodic solo parts are improvised in the act of performance, in whatever musical genre of Western popular music, having as a restriction only the stereotypes of the musical genres in which it is inserted. 


\section{MUSICAL COHERENCE}

How to determine if a piece of music is coherent? What is coherence and how could it be applicable to music? In Linguistics coherence is understood as a cognitive-conceptual resultant of the relations among several utterances of a given text (Marcuschi in Gomes, 2013) that by maintaining some unity among themselves, end up producing meaning in the text: "the authors are inclined to agree that coherence is something related to the meaning of the text, being a principle of interpretability that grants to the text a unity and relation among its elements" (Spinillo \& Martins, 1997, p. 3).

Despite of the difficulty of conceptualizing coherence (Koch \& Travaglia in Spinillo and Martins, 1997), it represents a key attribute, reaching the point of being considered a determining condition:

(...) coherence is generally invoked as a basic dimension of the Text, or even as a property that separates the Text from the "non-text", taking this as arbitrary or disconnected sequence of sentences (...). ${ }^{3}$ (Fonseca, 2020, p. 7).

From the previous quote we could attribute to the term "text" the meaning of a coherent sequence of sentences. n music, textual metaphors that appropriate the term "sentence" or even "text" are not rare, so the notion of musical coherence as a textual metaphor may even seem obvious. A coherent sequence of musical phrases could be interpreted as a network of relations that results in a cognitive-conceptual construction as described by Marcuschi (Gomes, 2013, p. 4) spawning meaning. Lawrence Zbikowski explains by a similar process the resources Richard Wagner utilizes in the opening of Tristan and Isolde: "by recalling specific motives at crucial points within his musical and dramatic discourse Wagner was able to create a sense of shape and unity that seemed inevitable without being predictable" (Zbikowski, 2002, p. 23). This recalling of specific motives could be exactly what is going to generate similarity relationships between pieces of the same music providing coherence to the musical discourse: "Coherence comes about when the various parts that make up a musical entity are connected in such a way that those parts similar to other entities become prominent." (Zbikowski, 2002, p. 27).

According to Zbikowski, "the key to musical coherence are the musical motives" (2002, p. 25), and these motives are described in Schoenberg words "as any one time the smallest part of a piece or section of a piece that, despite change and variation, is recognizable as present throughout" (In Zbikowski, 2002, p. 26). The musical motives in Zbikowski's view are crucial of musical meaning production because "The cognitive salience of the motive, (...), mirrors that of the basic level" (2002,

\footnotetext{
${ }^{3}$ (...) a coerência é generalizadamente invocada como dimensão basilar do Texto, ou mesmo como propriedade que separa o Texto do "não texto", tomando este como arbitrária ou desconexa sequência de frases (...).
} 
p. 34). Here we have the key-concept of Zbikowski's understanding of musical motive; He refers here to a basic level of categorization. Categorization is defined as the taxonomic grouping based on shared attributes (Rosch et al., 1976, p. 385), or yet, as an information optimization process that reduces it to a minimum:

\begin{abstract}
If they are to survive, all organisms must reduce the huge amount of information that comes in from the outside world, deciding which information is relevant to their survival. One of the primary mechanisms through which this is accomplished is categorization. A central mechanism of perception and semantic memory, categorization may be the primary basis of memory (...). It is here defined as the ability (1) to group features together and thereby differentiate objects, events, or qualities; and (2) to see some of these as equivalent, and associate and remember them together in a category. (Snyder, 2000, p. 81).
\end{abstract}

The basic level of categorization is the most useful. Is the one with the least demand on the cognitive apparatus yet with the maximum of information possible: "At the basic level, categories have lots of attributes while having relatively few contrast categories, which makes them informative at relatively low cost" (Tversky \& Hemenway, 1991, p. 439).

If motives are the musical equivalent of the perception of basic levels of categorization, then these are the musical elements most readily retained by the human apparatus responsible for the processes of categorization and therefore of meaning. Motives can be understood as musical recurrences happening all over the music-partial or integral repetitions of one or more musical elements that become prominent by repetition given the listener the experience of a kind of a reiteration of ideas-the motives make sense. However, motives should not be thought of as small fragments exclusively, they can be derived from broad and dynamic concepts (Schoenberg in Zbikowski, 2002, p. 26). The "reiteration of ideas" may occur in melodic passages, in rhythm figures, in melodic contours, in timbres, in dynamics, or in any other musical parameter. As long as they are repeated in along the music as coherence generators, they will grant the music with meaning.

\title{
4 FINAL CONSIDERATIONS
}

Musical cognition research usually emphasizes the process of musical meaning formation on the listener standpoint, restricting the study to the listener/musical work relationship. However, the very notion of musical work is itself object of many debates. For those who stands for the existence of a musical work there is yet the problem of its nature: it is a work or a musical process? For the advocates of the procedural view there remains another question: is the musical work in the music sheet or in the performance? Or even, is the performance a part of the generator process of the musical work? In the end, all these questions are based on the traditional idea of the European written music, from which, whether there is a work or not, whether it is an object or a process, it is understood that there is a score 
that would configure a starting point for musical performance, a script to be followed by the performer. Here my aim was a bit different: to understand the process of musical meaning formation not by a listener of a musical work (whether it exists or not), but I seek to analyze a situation in which the listener and the performer are fused in the same person, creating at least part of the music at the very moment of its performance, through improvisation, and listening to it for the first time.

To accomplish that, amidst all possibilities there are in music performance, it is important to precise what do I mean by jazz improvisation. I discussed and proposed exact meanings for the terms improvisation and jazz. For the first one I believe the best definition came from Nettl— "a musical work final form, while it is being executed" (2017). For jazz, I mean not anymore a musical genre exclusively, but a musical modus operandi practiced all around the world.

The concept of musical coherence is also crucial here. In order to get a clearer definition of coherence in music I started from an already established usage of textual metaphors applied to music, then moved on to some very promising musical cognition concepts such as categorization and the taxonomic basic level (as proposed by Zbikowski, 2002, Snyder, 2000 and Butterfield, 2002), and those applied to the idea of reiteration in musical discourse, recognizable recurrences of similarities like the expansion of Schoenberg's motives proposed by Zbikowski (2002).

The terminological clarification of what I understand here as jazz improvisation - the creation of improvised solo melodic parts in Western popular music genres - as well as the debate on the concept of musical coherence constitute a vital first step in the investigation of cognitive processes involved in the act of jazz improvisation. I propose the hypothesis that the understanding of coherence regulates improvisatory decisions and intend to continue the investigation by studying how the cognitive apparatus we call memory conditions and enables the formation of musical meaning in the act of improvisation. 


\section{REFERENCES}

Bailey, D. (1993). Improvisation: Its nature and practice in music. Cambridge, Da Capo Press.

Beckstead, D. (2013). Improvisation: Thinking and playing music. Music Educators Journal, 99(3), 69-74.

Butterfield, M. (2002). The musical object revisited. Music Analysis, 21(3), 327-380.

Cook, N. (2001). Between process and product: Music and/as performance. Music theory online, 7(2), $1-31$.

Fonseca, J. (2020). A coerência do texto. Revista da Faculdade de Letras-Línguas e Literaturas, 5(1). Gesell, I. (2006). Tools for transformation: Improving team performance through improvisation theater theory and techniques. The Journal for Quality and Participation, 29(3), 14.

Gioia, T. (1997). The history of jazz. Oxford University Press.

Gomes, A. L. L. (2013). A produção escrita de alunos com e sem síndrome de down: Uma análise da coerência textual. Educar em Revista, (47), 285-300.

Ingarden, R. (1986). The work of music and the problem of its identity. Univ of California Press.

Jackson, T. A. (2008). Jazz as musical practice. In M. Cooke \& D. Horn (Eds.), The Cambridge companion to jazz. Cambridge University Press.

Merlino, J. (2008). A cifragem alfanumérica-uma revisão conceitual.

Monson, I. T. (2008). Jazz improvisation. In M. Cooke \& D. Horn (Eds.), The Cambridge companion to jazz. Cambridge University Press.

Nettl, B., Wegman, R. C., Horsley, I., Collins, M., Carter, S. A., Garden, G., Seletsky, R. E., Levin, R. D., Crutchfield, W., Rink, J., Griffiths, P., \& Kernfeld, B. (2017). Jazz [Accessed: 2016-01-12]. Oxford Music Online. http://www.oxfordmusiconline. com / subscriber / article / grove / music / 13738pg3

Rosch, E., Mervis, C. B., Gray, W. D., Johnson, D. M., \& Boyes-Braem, P. (1976). Basic objects in natural categories. Cognitive psychology, 8(3), 382-439.

Rosenwald, L. (1993). Theory, text-setting, and performance. The Journal of Musicology, 11(1), 5265.

Sawyer, R. K. (1999). Improvisation. Journal of Linguistic Anthropology, 9(1/2), 121-123.

Snyder, B. (2000). Music and memory: An introduction. MIT press.

Spinillo, A. G., \& Martins, R. A. (1997). Uma análise da produção de histórias coerentes por crianças. Psicologia: Reflexão e Critica, 10(2), 219-248.

Tversky, B., \& Hemenway, K. (1991). Parts and the basic level in natural categories and artificial stimuli: Comments on murphy (1991). Memory \& cognition, 19(5), 439-442. 
Walser, R. (2008). Valuing jazz. In M. Cooke \& D. Horn (Eds.), The Cambridge companion to jazz. Cambridge University Press.

Zack, M. H. (2000). Jazz improvisation and organizing: Once more from the top. Organization Science, $11(2), 227-234$.

Zbikowski, L. M. (2002). Conceptualizing music: Cognitive structure, theory, and analysis. Oxford University Press on Demand. 